(c) American Dairy Science Association, 2007.

\title{
Production Effects of Pathogens Causing Bovine Leukosis, Bovine Viral Diarrhea, Paratuberculosis, and Neosporosis
}

\author{
A. Tiwari, ${ }^{\star 1}$ J. A. VanLeeuwen, ${ }^{*}$ I. R. Dohoo, ${ }^{*}$ G. P. Keefe, ${ }^{*}$ J. P. Haddad, ${ }^{*}$ R. Tremblay, $\dagger$ \\ H. M. Scott, $\ddagger$ and T. Whiting§ \\ *Department of Health Management, Atlantic Veterinary College, University of Prince Edward Island, Charlottetown, Canada C1A 4P3 \\ †Boehringer-Ingelheim Ltd. (Canada), 5180 South Service Rd., Burlington, Ontario, Canada, L7L 5H4 \\ ‡Department of Veterinary Integrative Biosciences, College of Veterinary Medicine and Biomedical Sciences, Texas A\&M University, \\ College Station 77843-4458 \\ §Manitoba Agriculture and Food, 545 University Cr., Winnipeg, Manitoba, Canada R3T 5S6
}

\begin{abstract}
The primary purpose of this research was to determine associations among seropositivity for bovine leukemia virus (BLV), bovine viral diarrhea virus (BVDV), Mycobacterium avium ssp. paratuberculosis (MAP), and Neospora caninum (NC) and each of 3 outcome variables (305-d milk, fat, and protein production) in Canadian dairy cattle. Serum samples from up to 30 randomly selected cows from 342 herds on monthly milk testing were tested for antibodies against BLV (IDEXX ELISA; IDEXX Corporation, Westbrook, ME), MAP (IDEXX or Biocor ELISA; Biocor Animal Health, Inc., Omaha, NE), and NC (IDEXX or Biovet ELISA; Biovet Inc., St. Hyacinthe, Quebec, Canada). Up to 5 unvaccinated cattle over 6 mo of age were tested for virusneutralizing antibodies to the Singer strain of type 1 BVDV. Dairy Herd Improvement records were obtained electronically for all sampled cows. Linear mixed models with herd and cow as random variables were fit, with significant restricted maximum likelihood estimates of outcome effects being obtained, while controlling for potential confounding variables. Bovine leukemia virus seropositivity was not associated with 305-d milk, 305$\mathrm{d}$ fat, or 305-d protein production. Cows in BVDV-seropositive herds (at least one unvaccinated animal with a titer $\geq 1: 64$ ) had reductions in 305-d milk, fat, and protein of 368, 10.2, and $9.5 \mathrm{~kg}$, respectively, compared with cows in BVDV-seronegative herds. Mycobacterium avium ssp. paratuberculosis seropositivity was associated with lower 305-d milk of $212 \mathrm{~kg}$ in 4+-lactation cows compared with MAP-seronegative 4+-lactation cows. Neospora caninum seropositivity in primiparous cows was associated with lower 305-d milk, fat, and protein of $158,5.5$, and $3.3 \mathrm{~kg}$, respectively, compared with NC-seronegative primiparous cows. There
\end{abstract}

Received March 26, 2006.

Accepted July 7, 2006.

${ }^{1}$ Corresponding author: atiwari@upei.ca were no interactions among seropositivity for any of the pathogens and their effects on any of the outcomes examined, although the low MAP seroprevalence limited this analysis. Results from this research will contribute to understanding the economic impacts of these pathogens and justify their control.

Key words: bovine viral diarrhea, paratuberculosis, neosporosis, milk production effects

\section{INTRODUCTION}

Infectious disease agents that can be harbored in apparently healthy animals, such as bovine leukemia virus (BLV), bovine viral diarrhea virus (BVDV), Mycobacterium avium ssp. paratuberculosis (MAP), and Neospora caninum (NC), are undergoing increasing scrutiny and research as a result of World Trade Organization regulations concerning animal health and animal movement between countries (WTO, 1994). In addition to the trade concerns, each of these organisms can lead to economic losses on infected farms. Based on an Atlantic Canadian (New Brunswick, NB; Nova Scotia, NS; and Prince Edward Island, PEI) prevalence survey of the 4 pathogens mentioned (Keefe and VanLeeuwen, 2000; VanLeeuwen et al., 2001) and literature estimates of associated costs, average direct farm costs were estimated for seropositive Atlantic Canadian dairy herds (Chi et al., 2002). The annual costs for BLV, BVDV, MAP, and NC were reported to be $\mathrm{CAN} \$ 806$, CAN $\$ 2,421, \operatorname{CAN} \$ 2,472$, and CAN $\$ 2,304$ per seropositive herd, respectively, assuming an average herd size of 50 cows, and average within-herd seroprevalences for BLV, MAP, and NC in seropositive herds of 31, 7, and $24 \%$, respectively (with BVDV tested only at the herd level). However, the literature estimates of associated costs were often inconsistent, limited, or both in their applicability to Canadian dairy herds; therefore, very conservative estimates of these effects were included in these cost estimates.

The effects of BLV seropositivity on milk production vary considerably in the published literature, from a 
negative relationship (Sargeant et al., 1997; D'Angelino et al., 1998) to either no relationship or even a positive relationship (Pollari et al., 1992). There are no published reports of the effects of BLV seropositivity on milk, fat, or protein production.

David et al. (1994) reported 23\% lower milk production over a 2 -wk period in affected cows in UK dairy herds experiencing BVDV outbreaks. Another study conducted in 13,971 Norwegian dairy herds, reported a $7 \%$ increase in the incidence of clinical mastitis in the year of apparent BVDV exposure (Waage, 2000). It is understandable that herds with outbreaks of clinically affected animals would likely have a low milk, fat, and protein production, but it is still unclear whether herds with apparently subclinically infected animals have lower milk, fat, or protein production compared with uninfected herds.

The published extent of milk production effects of subclinical MAP infection appears to depend on the herd productivity, stage of the disease, and test utilized to identify infected cows. The highest estimates include a $6 \%$ reduction in milk production in the second to last lactation and a $16 \%$ reduction in the final lactation prior to culling in histopathologically positive, subclinically infected cows compared with culled cows without histopathological evidence of MAP infection (Benedictus et al., 1987). However, $4 \%$ (376-kg) reductions in mature equivalent milk production in serum ELISA-positive cows in Wisconson have been reported, compared with serum ELISA-negative cows (Nordlund et al., 1996). A much larger reduction $(1,367 \mathrm{~kg}$, or $14 \%)$ in mature equivalent milk production was reported among cows testing strong positive, compared with test-negative cows, in a 16-state US study (Lombard et al., 2005). However, others have reported no significant decrease in milk production in ELISA seropositive and fecal culture-positive cows (Johnson et al., 2001), compared with test-negative cows.

The effects of MAP seropositivity on 305-d fat and 305-d protein production are not well documented and are less consistent in the published literature than effects on 305-d milk production. The relationship between MAP seropositivity and 305-d fat and 305-d protein production was not significant in 3 studies (Johnson et al., 2001; Hendrick et al., 2005; Lombard et al., 2005). However, the 305-d fat and protein were significantly lower in cows testing positive on fecal culture and milk ELISA in 9 herds in Ontario, and this reduction was not simply a reflection of lower milk production (Hendrick et al., 2005). The extent of the impact of MAP seropositivity, by lactation, on milk, fat, and protein production is still unclear.

Published reports on the effects of $\mathrm{NC}$ seropositivity on milk production are also not consistent. Neospora caninum-seropositive first-lactation heifers produced $384 \mathrm{~kg}$ less milk than $\mathrm{NC}$-seronegative first-lactation heifers in a 2,000-cow herd (Thurmond and Hietala, 1997). Neospora caninum-seropositive multiparous cows produced $385 \mathrm{~kg}$ less milk during their last lactations than did NC-seronegative multiparous cows in a 700-cow herd. (Hernandez et al., 2001). In contrast, NC seropositivity in a 600-cow dairy herd was associated with an increase of $0.4 \mathrm{~L} /$ cow per d of milk when compared with NC-seronegative cows (Pfeiffer et al., 2002). In a case-control study including dairy herds in Ontario, NC-seropositive cows in herds with abortion attributable to NC produced significantly less 305-d milk $(276 \mathrm{~kg})$ compared with NC-seronegative cows (Hobson et al., 2002). However, in the same project, the NCseropositive cows from 57 nonrandomly selected herds did not have a decrease in milk production when compared with NC-seronegative cows (Hobson et al., 2002). Therefore, it is still unclear whether NC seropositivity has an impact on milk production and whether this putative impact depends on factors such as age of the cow or whether the herd is experiencing abortion problems.

There is only one published study investigating the relationship between NC seropositivity and milk fat or protein production in a herd experiencing an abortion storm. In this study, NC seropositivity was associated with higher milk protein production in a 600-cow New Zealand dairy herd compared with NC-seronegative cows (Pfeiffer et al., 2002). There was no effect of NC seropositivity on milk fat in this study. It is unclear whether the outcome of this study would be consistent with randomly selected herds in other countries.

The results from the aforementioned studies on associations between these milk production variables and seropositivity for the 4 pathogens might not be representative of the true state of nature in the dairy industry in general (or Canadian dairy herds in particular) for one or more of the following reasons: 1) Many studies used a single large herd, which may not be representative of other large herds or small herds because of differences in management or seroprevalence. 2) If multiple herds were used, these herds were often not randomly selected, leading to possible herd selection bias. 3) Confounding variables, such as parity, were often not controlled for in the design or analyses. 4) Associations between the milk production variables and seropositivity for one pathogen may vary with coinfection with other pathogens (e.g., BLV and BVDV impair cellular immunity), and the effects of these coinfections have rarely been studied in the past.

The primary objective of this study was to determine the relationships among seropositivity for BLV, BVDV, MAP, and NC and each of 3 outcome variables (305-d 
milk, 305-d fat, and 305-d protein production) in Canadian dairy cattle while controlling for possible confounding variables, such as lactation number and seropositivity for the other pathogens, and adjusting for clustering at the lactation, cow, and herd levels. Secondary objectives were to determine the frequencies of cows with evidence of exposure for one or more of the 4 pathogens, and to determine the contribution of each level of the hierarchical structure (herd, cow, lactation) to the total variation of the 3 outcome variables.

The data used for this study were from recent prevalence surveys of Canadian dairy herds in PEI, NB, and NS (Keefe and VanLeeuwen, 2000; VanLeeuwen et al., 2001), Saskatchewan (SASK; VanLeeuwen et al., 2005), Ontario (ONT; Tiwari et al., 2004), Quebec (QUE; CQIASA, 2003), Manitoba (MAN; VanLeeuwen et al., 2006), and Alberta (ALTA; Scott et al., 2006). Nationally, 30.3, 3.1, and $11.4 \%$ of cows were seropositive for exposure to BLV, MAP, and NC, respectively. At the herd level, $76.6 \%$ of herds had at least one cow seropositive for BLV, and 18.9 and $64.8 \%$ of herds had at least 2 cows seropositive for MAP and NC, respectively. For BVDV, 36.5\% of the herds had at least one unvaccinated animal with a BVDV titer above 1:32. The sampling for these surveys is described briefly below.

\section{MATERIALS AND METHODS}

\section{Serum Sample Collection}

A stratified 2-stage random sampling procedure was used for serum sample collection. Herd-level inclusion criteria included participation in monthly milk recording; willingness to provide cattle for blood sampling and testing for antibodies to the 4 pathogens; and willingness to release the monthly milk recording data and results of the blood tests to the research team.

During the summer of 1998 in Atlantic Canada, dairy herds were randomly selected (using computer-generated random numbers) from eligible farms until 90 herds were recruited, 30 each from PEI, NB, and NS. Similar recruitment procedures were used to select 75 , 27, 40, 44, and 66 herds from the provinces of QUE, ONT, MAN, SASK, and ALTA in 2002, 1998, 2002, 2001 , and 2002, respectively. The number of herds recruited for this project from each province was restricted by the amount of funding that was available from provincial sources.

Approximately 30 lactating animals (fewer if the total number of cows in the herd was fewer than 30 cows) were randomly selected for blood collection and BLV, MAP, and NC testing in each participating herd. The sample size formula used to determine the number of required cows in each herd in eastern Canada assumed an average herd size of 45 lactating cows, an average within-herd prevalence estimate of $10 \%$, and confidence level of $90 \%$. Although average herd sizes were slightly larger in western Canada, a similar number of cows were sampled from western Canadian herds for consistent interpretation of seroprevalence results among provinces. Because one of the objectives of the study was to determine the effects on milk production for cows that were seropositive for more than one pathogen, cows of all ages were eligible for selection.

For BVDV testing in herds vaccinating for BVDV, 5 unvaccinated cattle $>6$ mo old were selected for blood collection to identify herds that were seropositive for BVDV. In unvaccinated herds, 5 of the 30 cows tested for the other 3 pathogens were selected. Within $24 \mathrm{~h}$ after collection, the blood samples were centrifuged, and the sera were harvested and stored at $-20^{\circ} \mathrm{C}$ until all the samples within a province were collected and ready for testing.

\section{Laboratory Analysis}

For all provinces, a cow was considered to be seropositive for BLV if the serum-to-positive ratio on the ELISA (IDEXX Corporation, Westbrook, ME) was $\geq 0.50$, as recommended by the manufacturer of the test kit (performance described by Johnson and Kaneene, 1991). The BLV ELISA kit also required a confirmation of positive tests, using a sample-to-negative host-cell ratio of $\geq 1.8$. The serum samples were tested in duplicate at all locations.

For all provinces, 5 serum samples/farm were tested for antibodies against the type 1 genotype BVD virus by using virus neutralization to the cytopathic Singer strain, as previously described (Deregt et al., 1992). An analysis of the distribution of titers showed that $>80 \%$ of herds with cattle having titers of $\geq 1: 64$ also had cattle with titers of 1:256 (the highest dilution tested). Conversely, $>80 \%$ of herds with cattle having titers of $1: 32$ did not have cattle with titers greater than 1:32. Therefore, a titer of $\geq 1: 64$ was determined to be a natural cut-point for this population and was used as a cutoff to describe the serological results for BVDV.

The test used by all provinces for MAP antibodies was also an ELISA, with ALTA cows being tested with one brand of ELISA (ELISA-A; Biocor Animal Health, Inc., Omaha, NE), according to the wishes of the directors of the study in that province (test performance described by Sockett et al., 1992). The cows in the rest of the participating provinces were tested with another ELISA (ELISA-B; IDEXX Corporation) that has been described previously (Dargatz et al., 2001). As recommended by the manufacturers of the test kits, an animal was considered to be seropositive for MAP if the optical density was greater than the mean of the negative con- 
Table 1. Tests and laboratories used for bovine leukemia virus (BLV), bovine viral diarrhea virus (BVDV), Mycobacterium avium ssp. paratuberculosis (MAP), and Neospora caninum (NC) testing of 342 dairy herds from 8 Canadian provinces

\begin{tabular}{|c|c|c|c|c|c|c|c|c|}
\hline \multirow[b]{2}{*}{ Province $^{1}$} & \multicolumn{2}{|r|}{ BLV } & \multicolumn{2}{|c|}{ BVDV } & \multicolumn{2}{|c|}{ MAP } & \multicolumn{2}{|c|}{$\mathrm{NC}$} \\
\hline & Diag test ${ }^{2}$ & Diag lab ${ }^{3}$ & Diag test & Diag lab & Diag test & Diag lab & Diag test & Diag lab \\
\hline LTA & IDEXX-E & Nat BLV Lab & VN-Singer & ADR Insti & BIOCOR-E & Alta Agri Lab & IDEXX-E & Alta Agri Lab \\
\hline MAN & IDEXX-E & Nat BLV Lab & VN-Singer & ADR Insti & IDEXX-E & Man Agri Lab & BIOVET-E & BIOVET Inc. \\
\hline NB & IDEXX-E & Nat BLV Lab & VN-Singer & ADR Insti & IDEXX-E & Prairie Diag & BIOVET-E & BIOVET Inc. \\
\hline NS & IDEXX-E & Nat BLV Lab & VN-Singer & $\mathrm{ADR}$ & IDEXX-E & Diag & OVET-E & BIOVET Inc. \\
\hline ONT & IDEXX-E & Nat BLV Lab & VN-Singer & ADR Insti & IDEXX-E & Prairie Diag & BIOVET-E & BIOVET Inc. \\
\hline PEI & IDEXX-E & Nat BLV Lab & VN-Singer & ADR Insti & IDEXX-E & Prairie Diag & BIOVET-E & BIOVET Inc. \\
\hline QUE $^{4}$ & IDEXX-E & Animal Path Lab & VN-Singer & ARM FRAPP & IDEXX-E & BIOVET Inc. & - & - \\
\hline SASK & IDEXX-E & Nat BLV Lab & VN-Singer & ADR Insti & IDEXX-E & Prairie Diag & BIOVET-E & BIOVET Inc. \\
\hline
\end{tabular}

${ }^{1}$ ALTA = Alberta; MAN = Manitoba; NB = New Brunswick; NS = Nova Scotia; ONT = Ontario; PEI = Prince Edward Island; QUE = Quebec; SASK = Saskatchewan.

${ }^{2}$ Diag test $=$ Diagnostic test $;-\mathrm{E}=$ ELISA; VN = virus neutralizing antibody test.

${ }^{3}$ Diag lab = Diagnostic laboratory; Nat BLV Lab = National BLV testing laboratory in Prince Edward Island (now in Quebec); Animal Path Lab = Quebec Animal Pathology Laboratory in Quebec, ADR Insti = Animal Diseases Research Institute in Alberta; ARM FRAPP = Armand Frappier Institute in Quebec; Alta Agri lab = Alberta Agriculture, Food and Rural Development Food Safety Division Laboratory; Man Agri Lab = Manitoba Agricultural Laboratory in Manitoba; Prairie Diag = Prairie Diagnostic Services in Saskatchewan; BIOVET Inc. = BIOVET Inc. laboratory in Quebec.

${ }^{4}$ The director of the study in Quebec elected not to test Quebec herds for Neospora caninum for financial reasons.

trol plus 0.100 for ELISA-A, and if the serum-to-positive ratio was $\geq 0.25$ for ELISA-B. The serum samples were tested in duplicate at all locations.

The test used by all provinces for NC antibodies was also an ELISA, with ALTA cows being tested with one brand of ELISA (ELISA-C; IDEXX Corporation), again according to the wishes of the directors of the study in that province (test previously described by Wu et al., 2002). The cows in the rest of the participating provinces (except Quebec, where herds were not tested for $\mathrm{NC}$ for financial reasons) were tested with another ELISA (ELISA-D; Biovet Inc., St. Hyacinthe, Quebec, Canada) that has been described previously (Bergeron et al., 2000). As recommended by the manufacturers of the test kits, a cow was considered to be seropositive for NC if the serum-to-positive ratio for ELISA-C and ELISA-D were $\geq 0.40$ and $\geq 0.60$, respectively. The serum samples were tested in duplicate at both locations.

Table 1 summarizes the laboratories and tests for each of the participating provinces. Reproducibility testing of sera was not performed at participating laboratories because of budgetary constraints.

\section{Data Collection}

For each tested cow, actual (305 DIM or more) and predicted (if 200 to 304 DIM) 305-d milk, fat, and protein production data; demographic data; and culling data from January 1, 1999, to December 31, 2003, were gathered electronically from a central milk-recording database. Therefore, there was one record for each lactation of each cow during this time period, with each record containing the 3 continuous outcome variables of interest: 305-d milk, 305-d fat, and 305-d protein. Cow records with lactation numbers $\geq 4$ were reclassified as lactation 4+ (allowing cows in lactation 3 to be analyzed separately from older cows) because of the small number of cows with more than 4 lactations.

\section{Statistical Analysis}

Standard descriptive statistics (means and 95\% confidence intervals) were calculated, along with contingency tables describing the distribution of cows seropositive to 1,2 , or 3 pathogens studied. Unconditional associations between the independent variables and each of the 3 outcome variables were computed in Stata (Version 8; Stata Corp., College Station, TX). Data for independent variables with unconditional associations significant at $P<0.15$ were transferred to MLwiN (Version 1.2; Center for Multilevel Modeling, Institute of Education, London, UK) to fit multilevel multivariable models.

The following approach was used for the multilevel multivariable linear regression modeling in MLwiN for each of the 3 outcome variables. Initially, restricted maximum likelihood estimates were obtained for a simple random intercept model containing only a constant (i.e., no other independent variables) to determine the distribution of variation of the 3 outcome variables among the 3 main levels (herd, animal, lactation) of data to guide the model-building process. Restricted maximum likelihood estimates were used because they are less prone to bias than the full maximum likelihood estimates (Kreft and De Leeuw, 1998). A forward stepwise approach to building each model was then used, 
retaining added variables in the model only if they were significant at $P \leq 0.05$. Serological results for the 4 pathogens were forced into each of the 3 final models to ensure that the potential effects of seropositivity for one pathogen were adjusted with respect to seropositivity for the other pathogens. The effects of seropositivity for BLV, BVDV, MAP, and NC on 305-d milk, 305-d fat, and 305-d protein were allowed to vary at the animal and herd levels by using random slope models that adjusted for clustering of lactations within cows and cows within herds. The correlations among lactations within a cow in our study were assumed to be equal because of the small number of lactations within each cow $($ mean $=2.3$ ). Correlations among cows within a herd were also assumed to be equal. Province was forced into each model to adjust for clustering of herds within a province because of significant clustering of serology results by province (A. Tiwari, unpublished data). The models of the effects of seropositivity for BLV, BVDV, $\mathrm{MAP}$, and NC on 305-d fat and 305-d protein production were estimated after controlling for 305-d milk production.

Effect modification was examined by creating firstorder interaction variables among the model variables. In particular, first-order interaction terms between seropositivity for each of the 4 pathogens and lactation number $(1,2,3$, and $4+)$ were examined to determine whether production effects associated with the pathogens may be occurring within specific lactations. Bovine viral diarrhea virus seropositivity was a herd-level variable; therefore, it had to be recoded in a manner that allowed determination of a cow-level interaction effect (on milk production) between BVDV status and lactation number. Therefore, all cows were coded as "seropositive" in a herd that was deemed seropositive for BVDV, and all cows were coded as "seronegative" in a herd that was deemed seronegative. This allowed for the cow-level interaction term to be created while maintaining the BVD status as a herd-level variable (no variability of cows within a herd).

To examine the possible effect of different tests being conducted in different laboratories, first-order interaction terms between the different laboratories and BLV, BVDV, MAP, and NC serostatus were also added to the final models and were removed if they did not remain significant $(P \leq 0.05)$.

The final models for all 3 outcome variables had the following general structure:

dependent variable (305-d milk, fat, or protein $)=$ constant + BLV + effect of BVDV seropositivity in 1st, 2nd, 3rd, and 4th+ lactations + effect of MAP seropositivity in 1st, 2nd, 3rd, and 4th+ lactations
Table 2. Comparison of the study population of 9,834 cows from 342 dairy herds with national dairy industry averages

\begin{tabular}{lll}
\hline & $\begin{array}{l}\text { Study } \\
\text { population } \\
\text { means }\end{array}$ & $\begin{array}{l}\text { Range of means } \\
\text { for Canadian } \\
\text { dairy industry } \\
\text { from } 1998 \text { to 2003 }\end{array}$ \\
\hline Item & 9,197 & 8,738 to 9,519 \\
Mean 305-d milk, kg & 333 & 323 to 351 \\
Mean 305-d fat, kg & 294 & 275 to 306 \\
\hline
\end{tabular}

+ effect of NC seropositivity in 1st, 2nd, 3rd, and 4th+ lactations + lactation number [1st (reference),

2nd, 3rd, and 4th+] + province [PEI (reference), NB, NS, QUE, ONT, MAN, SASK, ALTA]

+ herd level random effect + lactation level random effect + residuals.

In the model, constant was defined as the 305-d milk production of a cow, which was seronegative for all 4 pathogens and was in first lactation from PEI. The goodness-of-fit of the models was evaluated by examining normal probability plots of residuals and plots of residuals vs. predicted values to check on the assumptions of normality and homogeneity of variance.

\section{RESULTS}

\section{Descriptive Statistics}

The final data set contained 342 herds with 9,834 cows and 22,665 lactations from January 1, 1999, to December 31, 2003. There were, on average, 2.3 lactations/cow (maximum number of lactations/cow in the final data set was 4). The means of production data from the sampled cows were within the ranges of Canadian dairy industry averages from 1998 to 2003 (AAFC, 2006), indicating that the random selection of herds and cows in our study appeared to have produced a sample population that was representative of the Canadian dairy industry as a whole, as summarized in Table 2 .

A contingency table (Table 3) provides a breakdown of the distribution of test results by pathogen groupings. A total of 6,036 cows were seronegative for BLV, MAP, and $\mathrm{NC}$, and only 16 cows were seropositive for the 3 pathogens.

\section{Analytical Statistics}

There was no significant effect modification of seropositivity for any of the pathogens by other pathogens 
Table 3. Number of cows for each combination of serology results ${ }^{1}$ for bovine leukemia virus (BLV), Mycobacterium avium ssp. paratuberculosis (MAP), and Neospora caninum (NC) in 342 Canadian dairy herds

\begin{tabular}{llll}
\hline Number of cows & BLV & MAP & NC \\
\hline 6,036 & 0 & 0 & 0 \\
2,367 & 1 & 0 & 0 \\
207 & 0 & 1 & 0 \\
682 & 0 & 0 & 1 \\
103 & 1 & 1 & 0 \\
382 & 1 & 0 & 1 \\
41 & 0 & 1 & 1 \\
16 & 1 & 1 & 1 \\
\hline
\end{tabular}

${ }^{1} 0=$ Seronegative cow for a pathogen; 1 = seropositive cow for a pathogen.

in any of the models. The normal probability plots of residuals, and plots of residuals vs. predicted values for all of the final models indicated that the basic assumptions of normality and homogeneity of variance were not violated for any of the models fit.

With no fixed effects in the models, the proportions of variance at the lactation and cow levels were somewhat higher for 305-d fat than for 305-d milk or 305-d protein, whereas variance at the herd level was somewhat higher for 305-d milk and protein than for 305-d fat (Table 4). When the significant fixed effects were in the final models, the proportion of variance estimates at the cow and herd levels were increased, whereas the proportion of variance estimates at the lactation level were decreased (results not shown).

305-d Milk Production Modeling. In Table 5, lactation number was not only a significant predictor of 305$\mathrm{d}$ milk production, as expected (with increasing milk production as parity increases), but it was also a significant effect modifier of the effect of seropositivity for BVDV, MAP, and NC on milk production (i.e., their effects depended on the lactation number). Therefore, the coefficients for the effects of seropositivity for BVDV, MAP, and NC were stratified by lactation categories. Within each lactation category for each pathogen, the coefficient is describing the difference in milk production between seropositive and seronegative cat-

Table 4. Percentage of the variance explained at each level of the hierarchy for 305-d milk, 305-d fat, and 305-d protein (no fixed effects in model) in 342 dairy herds with 9,834 cows from 8 provinces in Canada

\begin{tabular}{llll}
\hline & \multicolumn{3}{c}{ Proportion of variance, \% } \\
\cline { 2 - 4 } $\begin{array}{l}\text { Source } \\
\text { of variation }\end{array}$ & $\begin{array}{l}\text { 305-d } \\
\text { milk }\end{array}$ & $\begin{array}{l}305-\mathrm{d} \\
\text { fat }\end{array}$ & $\begin{array}{l}\text { 305-d } \\
\text { protein }\end{array}$ \\
\hline Herd & 35.8 & 28.7 & 37.9 \\
Cow & 21.4 & 24.1 & 19.4 \\
Lactation & 42.8 & 47.2 & 42.7 \\
\hline
\end{tabular}

tle (the reference group) for that pathogen within that parity.

There was no significant relationship between BLV seropositivity and 305-d milk production. Across all lactations, cows in BVDV-seropositive herds had a lower $305-\mathrm{d}$ milk production of $368 \mathrm{~kg} / \mathrm{cow}$ compared with cows in BVDV-seronegative herds (not shown in Table 5 ), with this effect being larger for cows in lactations 2 and 3 (Table 5). Mycobacterium avium ssp. paratuberculosis seropositivity in 4+-lactation cows was significantly associated with a lower 305-d milk production of $212 \mathrm{~kg}$. Neospora caninum seropositivity in first-lactation heifers was significantly associated with a lower $305-\mathrm{d}$ milk production of $158 \mathrm{~kg}$. The MAP and NC estimates for other parities were not significant at $P$ $<0.05$, but overall, the interactions between lactation number and NC and MAP seropositivity were significant.

305-d Fat Production Modeling. The results from the 305-d fat production modeling were similar to the 305-d milk production results (results not shown). Cows in BVDV-seropositive herds had a marginally lower $305-\mathrm{d}$ fat production of $10.2 \mathrm{~kg}(P=0.052)$ compared with cows in BVDV-seronegative herds. Neospora caninum seropositivity in first-lactation heifers was significantly associated with a lower $305-\mathrm{d}$ fat of $5.54 \mathrm{~kg}$ $(P=0.027)$. There was no significant relationship between BLV or MAP seropositivity and 305-d fat production. After controlling for 305-d milk, BVDV and NC seropositivity were no longer associated with 305-d fat production.

305-d Protein Production Modeling. The results from the 305-d protein production modeling were also similar to the 305-d milk results (results not shown). Cows in BVDV-seropositive herds had a significantly lower 305-d protein production of $9.35 \mathrm{~kg}(P=0.036)$ compared with cows in BVDV-seronegative herds. Neospora caninum seropositivity in first-lactation heifers was associated with a marginally lower 305 -d protein production of $3.30 \mathrm{~kg}(P=0.080)$. Bovine leukemia virus- and MAP-seropositive cows were not significantly associated with 305-d protein production. After controlling for 305-d milk, BVDV seropositivity was no longer associated with $305-$ d protein production.

\section{DISCUSSION}

This study is unique because it is the first published report of the relationships among seropositivity for 4 pathogens (BLV, BVDV, MAP, and NC) and each of 3 outcome variables (305-d milk, 305-d fat, and 305-d protein production). Furthermore, it was conducted in a highly representative population of dairy cattle while controlling for clustering of lactations, cows, and herds 
Table 5. Final model of associations between 305-d milk production (kg) and seropositivity for bovine leukemia virus (BLV), bovine viral diarrhea virus (BVDV), Mycobacterium avium ssp. paratuberculosis (MAP), and Neospora caninum (NC; by lactation number) from multilevel linear regression analyses of 22,665 lactations in 9,834 dairy cows in 342 Canadian dairy herds

\begin{tabular}{|c|c|c|c|c|}
\hline Fixed effect variables & $\mathrm{n}^{1}$ & Estimate & SE & $P$-value \\
\hline Constant & - & $7,033.1$ & 233.2 & 0.001 \\
\hline BLV & 7,200 & 36.1 & 34.8 & 0.300 \\
\hline BVDV $^{2}$ & & & & 0.001 \\
\hline Lactation 1 & 1,542 & -348.1 & 155.0 & \\
\hline Lactation 2 & 1,620 & -427.6 & 154.7 & \\
\hline Lactation 3 & 1,316 & -410.2 & 155.9 & \\
\hline Lactation 4+ & 1,966 & -302.3 & 155.6 & \\
\hline MAP $^{3}$ & & & & 0.004 \\
\hline Lactation 1 & 223 & 125.6 & 99.6 & \\
\hline Lactation 2 & 231 & 45.8 & 98.1 & \\
\hline Lactation 3 & 204 & 135.8 & 102.9 & \\
\hline Lactation $4+$ & 230 & -212.1 & 107.4 & \\
\hline $\mathrm{NC}^{3}$ & & & & 0.001 \\
\hline Lactation 1 & 636 & -158.1 & 63.1 & \\
\hline Lactation 2 & 660 & -58.5 & 61.9 & \\
\hline Lactation 3 & 576 & 91.0 & 65.2 & \\
\hline Lactation 4+ & 821 & 45.6 & 64.4 & \\
\hline Lactation & & & & 0.001 \\
\hline 1 & 5,886 & Reference group & - & \\
\hline 2 & 5,761 & $1,306.2$ & 29.8 & \\
\hline 3 & 4,521 & $1,845.0$ & 33.8 & \\
\hline$\geq 4$ & 6,497 & $2,000.8$ & 35.7 & \\
\hline Province & & & & 0.001 \\
\hline Prince Edward Island & 1,955 & Reference group & - & \\
\hline New Brunswick & 1,803 & -255.5 & 308.9 & \\
\hline Nova Scotia & 1,826 & 741.2 & 308.0 & \\
\hline Quebec & 4,340 & 707.8 & 259.3 & \\
\hline Ontario & 1,668 & $1,438.1$ & 317.9 & \\
\hline Manitoba & 2,504 & $1,423.2$ & 298.8 & \\
\hline Saskatchewan & 2,913 & $1,058.6$ & 290.5 & \\
\hline Alberta & 5,656 & $1,327.6$ & 282.5 & \\
\hline
\end{tabular}

\footnotetext{
${ }^{1}$ Number of observations for Lactation and Province, number of test-positive observations for BLV, MAP, and NC (by lactation, where applicable), and number of observations in herds testing positive for BVDV (by lactation).

${ }^{2}$ Estimates equal the average difference in 305 -d milk between cows in test-positive herds (having at least 1 animal with a titer $\geq 1: 64$ ) and cows in test-negative herds, by lactation.

${ }^{3}$ Estimates equal the average difference in $305-\mathrm{d}$ milk between test-positive and test-negative cows, by lactation.
}

and controlling for possible confounding variables, such as lactation number and seropositivity for the other pathogens, by using multilevel models. Most investigations determining production effects of pathogens have been conducted with testing for exposure to only one pathogen of interest. The study population was highly representative of the Canadian dairy industry because farms in 8 out of the 10 Canadian provinces (which comprised $>95 \%$ of dairy herds in Canada; AAFC, 2006) participated in this study, and random selection procedures at the herd and cow level were used for serum sample collection. Comparison of production variables calculated from the study population with national industry averages confirmed this representativeness.

There were no significant interactions between seropositivity for any of the pathogens in terms of their effects on 305-d milk, fat, and protein. It is possible that there truly were no interactive effects from sero- positivity for more than one of the pathogens tested in our study, but there are other possible explanations for not detecting any interactions. First, limited numbers (Table 3) of cattle in our study were seropositive for multiple pathogens, providing somewhat limited power to detect interactions between pathogens. In particular, because of the low sensitivity of ELISA to detect MAPinfected cattle (Dargatz et al., 2001), the low number of MAP-seropositive cows limited the power to detect interactions involving MAP. Also, MAP infection frequently progresses only to clinical signs of chronic diarrhea in mature cows (Wilson et al., 1993), whereas the most frequent times for cows to abort from $\mathrm{NC}$ infection are during their first pregnancy as a heifer and during their second pregnancy as a first-lactation cow (Pfeiffer et al., 2002). If clinical manifestations do not frequently coincide in time, then it is reasonable to believe that 
any subclinical impacts on milk production frequently may not coincide in time either.

Based on the multilevel models, a high percentage of the variation in the milk production indices was at the lactation level, with lesser amounts at the cow and herd level. Significant associations were detected for MAP and NC seropositivity, but only for certain lactations. Therefore, efforts to reduce transmission of MAP and NC should be made at the animal and herd levels, but efforts to reduce impacts on milk production should be focused at the lactation level. For example, cows that are seropositive for MAP and are confirmed to be fecal culture-positive for MAP should be culled as soon as possible to reduce transmission to other animals on the farm and also possibly reduce the impact of MAP infection on milk production. Similarly, first-calf heifers that are seropositive for $\mathrm{NC}$ could be put on the "do not breed" list or sold in early gestation prior to the risk period for abortion to reduce the risk of an abortion occurring in that animal on that farm and subsequently having a negative impact on milk production (and possibly spreading NC to other animals on the farm through canid horizontal transmission). Of course, other factors, such as genetic value, milk production, and number of NC-seropositive cattle, would also have to be considered in this decision. For BVD, there was not a substantial difference among lactations in the association between milk production and BVD seropositivity at the herd level; therefore, efforts to reduce the impacts of BVD seropositivity on milk production should not differ among lactations.

In our study, data from all available lactations for the sampled cattle were included in the final data set for 2 reasons. First, infection with these pathogens is frequently occurring in utero or in young animals. Most cattle infected with $\mathrm{NC}$ are infected in utero (Pare et al., 1996), cattle persistently infected with BVDV are infected in utero (Houe, 1995), and many cattle infected with BLV are infected early in life (Dimmock et al., 1991). Furthermore, it is well accepted in the scientific literature that the susceptibility of infection with MAP is highest among calves and decreases with age, although these statements are based on limited scientific reports (Hagan, 1938; Larsen et al., 1975). Furthermore, using all lactations would provide more statistical power to detect significant differences between seropositive and seronegative cows and herds, which would be particularly useful for detecting parity differences attributable to MAP seropositivity with the low MAP seroprevalence.

There was no way to know when infection occurred in each animal in the sample population. However, BLV and BVDV transmission also likely occurred among adults (Detilleux et al., 1991; David et al., 1994). There- fore, a subset analysis was conducted using only the lactations in which the blood testing occurred (median and maximum number of lactations both equal to one). This subset analysis produced very similar regression coefficients but less statistically significant results (results not shown) compared with when all lactations were included. Therefore, the analyses and results including all lactations are provided.

\section{$B L V$}

Relationships between BLV seropositivity and milk production and fat have been reported (Jacobs et al., 1991; Pollari et al., 1992), but these studies either included small numbers of herds with high seroprevalence or had inappropriate control of confounding variables or adjustments for clustering. After controlling for herd size and age, no significant relationships were found between BLV seropositivity and milk production (Jacobs et al., 1991). In our study of randomly selected cows and herds with a wide variety of seroprevalences, after controlling for age and the effects of other infective agents, seropositivity for BLV was not associated with 305-d milk, 305-d fat, or 305-d protein.

\section{$B V D V$}

Cows in BVDV-seropositive herds were significantly associated with lower milk production, fat, and protein compared with cows in BVDV-seronegative herds. The pathogenesis underlying this relationship is unclear, but a number of hypotheses are possible, including subclinical or clinical disease related to mastitis or abortion.

A Norwegian study found increased incidence rates of clinical mastitis in herds with elevated antibody titers to BVDV in bulk tank milk (Waage, 2000). It is unknown whether the BVDV-seropositive herds in our study were undergoing clinical manifestations of BVDV infection, leading to increased clinical mastitis and subsequent reduced milk production. In a related study, we found that cows in BVDV-seropositive herds had a 1.86 and 1.43 times higher hazard of culling for low milk production than cows in BVDV-seronegative herds (Tiwari et al., 2005).

In a British study (David et al., 1994), there was a $23 \%$ loss in milk production following abortions caused by BVDV. The risk of abortion among susceptible cattle that become infected with BVDV has been reported to vary from $4.8 \%$ in Denmark (Meyling et al., 1990) to $26 \%$ in England (Murray, 1990). Therefore, abortions caused by BVDV seropositivity also may have contributed to a loss of milk, fat, and protein production.

The herds were not tested for antibodies against type 2 BVDV because of insufficient funding. Therefore, 
some herds that were negative for type 1 BVDV may have been false negatives if type 2 BVDV was in the herd. The implication of this possible misclassification is that milk production among the herds classified as BVDV-negative would likely be lower than if all herds testing negative were truly negative. As a result, the actual reduction in milk production from being BVDVpositive would likely be even larger than what was observed.

\section{MAP}

Our study results of a reduction in milk production in MAP-seropositive 4+-lactation cows support conclusions made previously (Wilson et al., 1993) that the effect of MAP seropositivity on milk production largely depends on the parity of the cow. This effect modification of parity may assist in understanding the wide range of results from previous studies. A study that found no effect (Johnson et al., 2001) likely did not have enough cows in later parities to detect a significant association. Conversely, the finding of $16 \%$ lower milk production in fecal culture-positive cows compared with fecal culture-negative cows was found in subclinical cows during the lactation just prior to culling, cows that would likely be older and in late stages of Johne's disease (Benedictus et al., 1987).

Our results of no effect of MAP seropositivity on 305$\mathrm{d}$ fat and 305-d protein production, after controlling for 305-d milk, support results from 3 previous studies (Johnson et al., 2001; Hendrick et al., 2005; Lombard et al., 2005). However, 305-d fat and protein were significantly lower in cows testing positive on fecal culture and milk ELISA in 9 herds in Ontario, and this reduction was not simply a reflection of lower milk production (Hendrick et al., 2005). Further research on the impacts of MAP on 305-d fat and 305-d protein are necessary.

The results of our study likely represent conservative estimates of MAP seropositivity on 305-d milk, 305-d fat, and 305-d protein because of the misclassification bias associated with ELISA results for MAP. Because of the very poor sensitivity of ELISA for MAP exposure, ranging from 8 to $80 \%$ (Sockett et al., 1992; McKenna et al., 2004), depending on the stage of infection of the test population, numerous infected animals likely gave false negative test results. Specificity of ELISA for MAP exposure is also not ideal, ranging from 90 to $99 \%$ (Dargatz et al., 2001), particularly when used on a large number of animals in a low-prevalence population, leading to numerous false positive test results. The impact of these misclassifications, assuming they are not differential in nature (other than with respect to age), would bias these model estimates toward the null. Results for ELISA are not as accurate at fecal culture test results, but ELISA are still widely used for practical reasons of low cost and quick turnaround of results. Therefore, it is important to understand the production impacts associated with being ELISA-positive to assist producers with management and culling decisions. Fecal cultures were not used in this study for reasons of cost because of the large sample population tested.

\section{NC}

Our finding of NC-seropositive first-lactation heifers having a 161-kg lower 305-d milk production compared with NC-seronegative first-lactation heifers confirms that this relationship is applicable to a variety of herd sizes and management levels of dairy farms and not just on a single 2,000-cow Holstein herd in California (Thurmond and Hietala, 1997) or 28 dairy herds in Ontario (Hobson et al., 2002) with a history of abortion problems associated with NC. In the case-control study in Ontario, NC seropositivity was significantly associated with a decrease of $276 \mathrm{~kg}$ in $305-\mathrm{d}$ milk production $(P \leq 0.05$; Hobson et al., 2002). Our lower estimate of impact on 305-d milk production may be due to the mixing of NC-seropositive herds with and without active abortion problems (data on abortions were not available).

We also found that seropositivity for NC in first-lactation heifers was associated with lower 305-d fat and protein production compared with $\mathrm{NC}$-seronegative first-lactation heifers, although this effect was no longer significant when we controlled for 305-d milk production. Conversely, in one New Zealand herd, NC seropositivity was associated with higher milk protein (Pfeiffer et al., 2002). However, the effect of NC on different lactations was not determined in that study.

The biological rationale of reduced milk production because of NC seropositivity in first-lactation heifers is still not clear, but may be related to reduced milk production after an abortion in first-lactation heifers. The major clinical effect of $\mathrm{NC}$ in cattle is abortion, and the percentage of abortions among dairy cattle attributed to NC has been estimated at between 12.5 (Davison et al., 1999) and 38.7\% (Mainar-Jaime et al., 1999), making it one of the most common causes of abortion in cattle. The abortion risk is highest in cows $4 \mathrm{yr}$ old or younger (Thornton et al., 1994) and decreases with the age of the cow (Pfeiffer et al., 2002). Dijkstra et al. (2003) showed that cattle produce less milk following $\mathrm{NC}$ abortion, perhaps related to abortion sequelae, such as retained afterbirth and metritis.

\section{CONCLUSIONS}

Bovine leukemia virus seropositivity was not associated with production of 305-d milk, fat, or protein. 
When all lactations were pooled together, the cows in BVDV-seropositive herds had lower 305-d milk, 305-d fat, and 305-d protein production. Mycobacterium avium ssp. paratuberculosis seropositivity in 4+-lactation cows was significantly associated with lower 305d milk, compared with MAP-seronegative 4+-lactation cows. Neospora caninum seropositivity in first-lactation heifers was significantly associated with lower 305-d milk and 305-d fat production compared with NC-seronegative first-lactation heifers. There were no interactions between seropositivity for the 4 pathogens and the 3 outcome variables investigated. Results from our research will provide a better understanding of the economic impacts of these pathogens and a justification for their control.

\section{ACKNOWLEDGMENTS}

The authors wish to acknowledge the following people for their technical and logistical support in the collection of samples and data from the participating farmers in Saskatchewan, Manitoba, and Alberta: LeeAnn Forsythe and Renee Chartier of the Saskatchewan Department of Agriculture, Food and Rural Revitalization (Inspection and Regulatory Management Branch, Animal Health Unit); Karen Kemp of Manitoba Agriculture and Food; the accredited Johne's disease veterinarians of Alberta; and laboratory scientists and staff of Alberta Agriculture, Food and Rural Development. The authors also wish to acknowledge the following funding sources: Dairy Farmers of Canada, Dairy Herd Improvement companies, Canadian Food Inspection Agency, Production Limiting Diseases Committee, Atlantic Veterinary College, Dairy Farmers of PEI, PEI Agricultural Research Investment Fund, Dairy Farmers of Ontario, Manitoba Agriculture, Saskatchewan Agriculture, Western Economic Partnership Agreement, and the Food Safety Division of Alberta Agriculture, Food and Rural Development.

\section{REFERENCES}

AAFC (Agriculture and Agri-Food Canada). 2006. Dairy Animal Improvement Statistics. http://www.dairyinfo.gc.ca/pdf/statsbook 2005.pdf Accessed Nov. 3, 2006.

Benedictus, G., A. A. Dijkhuizen, and J. Stelwagen. 1987. Economic losses due to paratuberculosis in dairy cattle. Vet. Rec. 121:142-146.

Bergeron, N., G. Fecteau, J. Pare, R. Martineau, and A. Villeneuve. 2000. Vertical and horizontal transmission of Neospora caninum in dairy herds in Quebec. Can. Vet. J. 41:464-467.

Chi, J., J. A. Vanleeuwen, A. Weersink, and G. P. Keefe. 2002. Direct production losses and treatment costs from bovine viral diarrhoea virus, bovine leukosis virus, Mycobacterium avium subspecies paratuberculosis, and Neospora caninum. Prev. Vet. Med. 55:137-153.

CQIASA (Centre Québécois d'inspection des aliments et de santé animale). 2003. Rapport final: Enquête de prévalence de la para- tuberculose, de la leucose bovine enzootique et des immunotolérants à la diarrhée virale bovine dans les troupeaux laitiers du Québec. CQIASA, Québec, Canada.

D'Angelino, J. L., M. Garcia, and E. H. Birgel. 1998. Productive and reproductive performance in cattle infected with bovine leukosis virus. J. Dairy Res. 65:693-695.

Dargatz, D. A., B. A. Byrum, L. K. Barber, R. W. Sweeney, R. H. Whitlock, W. P. Shulaw, R. H. Jacobson, and J. R. Stabel. 2001. Evaluation of a commercial ELISA for diagnosis of paratuberculosis in cattle. J. Am. Vet. Med. Assoc. 218:1163-1166.

David, G. P., T. R. Crawshaw, R. F. Gunning, R. C. Hibberd, G. M. Lloyd, and P. R. Marsh. 1994. Severe disease in adult dairy cattle in three UK dairy herds associated with BVD virus infection. Vet. Rec. 134:468-472.

Davison, H. C., A. Otter, and A. J. Trees. 1999. Significance of Neospora caninum in British dairy cattle determined by estimation of seroprevalence in normally calving cattle and aborting cattle. Int. J. Parasitol. 29:1189-1194.

Deregt, D., S. Smithson, and G. C. Kozub. 1992. A short incubation serum neutralization test for bovine viral diarrhea virus. Can. J. Vet. Res. 56:161-164.

Detilleux, J. C., A. E. Freeman, and L. D. Miller. 1991. Comparison of natural transmission of bovine leukemia virus in Holstein cows of two genetic lines selected for high and average milk production. Am. J. Vet. Res. 52:1551-1555.

Dijkstra, T., H. W. Barkema, M. Eysker, M. L. Beiboer, and W. Wouda. 2003. Evaluation of a single serological screening of dairy herds for Neospora caninum antibodies. Vet. Parasitol. 110:161-169.

Dimmock, C. K., Y. S. Chung, and A. R. MacKenzie. 1991. Factors affecting the natural transmission of bovine leukaemia virus infection in Queensland dairy herds. Aust. Vet. J. 68:230-233.

Hagan, W. A. 1938. Age as a factor in susceptibility to Johne's disease. Cornell Vet. 28:34-40.

Hendrick, S. H., D. Kelton, K. E. Leslie, K. D. Lissemore, M. Archambault, and T. F. Duffield. 2005. Effect of paratuberculosis on culling, milk production, and milk quality in dairy herds. J. Am. Vet. Med. Assoc. 227:1302-1308.

Hernandez, J., C. Risco, and A. Donovan. 2001. Association between exposure to Neospora caninum and milk production in dairy cows. J. Am. Vet. Med. Assoc. 219:632-635.

Hobson, J. C., T. F. Duffield, D. Kelton, K. Lissemore, S. K. Hietala, K. E. Leslie, B. McEwen, G. Cramer, and A. S. Peregrine. 2002. Neospora caninum serostatus and milk production of Holstein cattle. J. Am. Vet. Med. Assoc. 221:1160-1164.

Houe, H. 1995. Epidemiology of bovine viral diarrhea virus. Vet. Clin. North Am. Food Anim. Pract. 11:521-547.

Jacobs, R. M., J. L. Heeney, M. A. Godkin, K. E. Leslie, J. A. Taylor, C. Davies, and V. E. Valli. 1991. Production and related variables in bovine leukaemia virus-infected cows. Vet. Res. Commun. 15:463-474.

Johnson, R. J., and J. B. Kaneene. 1991. Bovine leukemia virus. Part I. Descriptive epidemiology, clinical manifestations, and diagnostic tests. Compend. Contin. Educ. Proc. Vet. 13:315-325.

Johnson, Y. J., J. B. Kaneene, J. C. Gardiner, J. W. Lloyd, D. J. Sprecher, and P. H. Coe. 2001. The effect of subclinical Mycobacterium paratuberculosis infection on milk production in Michigan dairy cows. J. Dairy Sci. 84:2188-2194.

Keefe, G. P., and J. A. VanLeeuwen. 2000. Neospora then and now: Prevalence of Neospora caninum in Maritime Canada in 1979, 1989, and 1998. Can. Vet. J. 41:864-866.

Kreft, I., and J. De Leeuw. 1998. Introducing Multilevel Modeling. Sage, London, UK

Larsen, A. B., R. S. Merkal, and R. C. Cutlip. 1975. Age of cattle as related to resistance to infection with Mycobacterium paratuberculosis. Am. J. Vet. Res. 36:255-257.

Lombard, J. E., F. B. Garry, B. J. McCluskey, and B. A. Wagner. 2005. Risk of removal and effects on milk production associated with paratuberculosis status in dairy cows. J. Am. Vet. Med. Assoc. 227:1975-1981.

Mainar-Jaime, R. C., M. C. Thurmond, B. Berzal-Herranz, and S. K. Hietala. 1999. Seroprevalence of Neospora caninum and abortion in dairy cows in northern Spain. Vet. Rec. 145:72-75. 
McKenna, S. L., G. P. Keefe, H. W. Barkema, J. McClure, J. A. Vanleeuwen, P. Hanna, and D. C. Sockett. 2004. Cow-level prevalence of paratuberculosis in culled dairy cows in Atlantic Canada and Maine. J. Dairy Sci. 87:3770-3777.

Meyling, A., H. Houe, and A. M. Jensen. 1990. Epidemiology of bovine virus diarrhoea virus. Rev. Sci. Technol. 9:75-93.

Murray, R. D. 1990. A field investigation of causes of abortion in dairy cattle. Vet. Rec. 127:543-547.

Nordlund, K. V., W. J. Goodger, J. Pelletier, and M. T. Collins. 1996. Associations between subclinical paratuberculosis and milk production, milk components, and somatic cell counts in dairy herds. J. Am. Vet. Med. Assoc. 208:1872-1876.

Pare, J., M. C. Thurmond, and S. K. Hietala. 1996. Congenital Neospora caninum infection in dairy cattle and associated calfhood mortality. Can. J. Vet. Res. 60:133-139.

Pfeiffer, D. U., N. B. Williamson, M. P. Reichel, J. J. Wichtel, and W. R. Teague. 2002. A longitudinal study of Neospora caninum infection on a dairy farm in New Zealand. Prev. Vet. Med. $54: 11-24$.

Pollari, F. L., V. L. Wangsuphachart, R. F. DiGiacomo, and J. F. Evermann. 1992. Effects of bovine leukemia virus infection on production and reproduction in dairy cattle. Can. J. Vet. Res. 56:289-295.

Sargeant, J. M., D. F. Kelton, S. W. Martin, and E. D. Mann. 1997. Associations between farm management practices, productivity, and bovine leukemia virus infection in Ontario dairy herds. Prev. Vet. Med. 31:211-221.

Scott, H. M., O. Sorenson, J. T. Wu, E. Y. Chow, K. Manninen, and J. A. VanLeeuwen. 2006. Seroprevalence of Mycobacterium avium subspecies paratuberculosis, Neospora caninum, bovine leukemia virus, and bovine viral diarrhea virus infection among dairy cattle and herds in Alberta and agroecological risk factors associated with seropositivity. Can. Vet. J. 47:981-991.

Sockett, D. C., T. A. Conrad, C. B. Thomas, and M. T. Collins. 1992. Evaluation of four serological tests for bovine paratuberculosis. J. Clin. Microbiol. 30:1134-1139.

Thornton, R. N., A. Gajadhar, and J. Evans. 1994. Neospora abortion epidemic in a dairy herd. N. Z. Vet. J. 42:190-191.

Thurmond, M. C., and S. K. Hietala. 1997. Effect of Neospora caninum infection on milk production in first-lactation dairy cows. J. Am. Vet. Med. Assoc. 210:672-674.
Tiwari, A., J. A. Vanleeuwen, I. R. Dohoo, J. P. Haddad, and G. P. Keefe. 2004. Seroprevalence and spatial distribution of bovine leukemia virus, bovine viral diarrhoea virus, Mycobacterium avium ssp. paratuberculosis, and Neospora caninum in Canadian dairy cattle. GISVET Conf., Univ. Guelph, Ontario, Canada. http://gisvet.org/Documents/GisVet04/Poster/Tiwara.pdf Accessed Mar. 10, 2006.

Tiwari, A., J. A. Vanleeuwen, I. R. Dohoo, H. Stryhn, G. P. Keefe, and J. P. Haddad. 2005. Effects of seropositivity for bovine leukemia virus, bovine viral diarrhoea virus, Mycobacterium avium subspecies paratuberculosis, and Neospora caninum on culling in dairy cattle in four Canadian provinces. Vet. Microbiol. 109:147-158.

VanLeeuwen, J. A., G. P. Keefe, R. Tremblay, C. Power, and J. J. Wichtel. 2001. Seroprevalence of infection with Mycobacterium avium ssp. paratuberculosis, bovine leukemia virus, and bovine viral diarrhea virus in maritime Canada dairy cattle. Can. Vet. J. 42:193-198.

VanLeeuwen, J. A., A. Tiwari, L. Forsythe, and R. Chartier. 2005. Seroprevalence of antibodies against bovine leukemia virus, bovine viral diarrhea virus, Mycobacterium avium ssp. paratuberculosis and Neospora caninum in Saskatchewan dairy cattle. Can. Vet. J. 46:56-58.

VanLeeuwen, J. A., A. Tiwari, J. C. Plaizier, and T. Whiting. 2006. Seroprevalence of antibodies against bovine leukemia virus, bovine viral diarrhea virus, Mycobacterium avium subspecies paratuberculosis and Neospora caninum in beef and dairy cattle in Manitoba. Can. Vet. J. 47:783-786.

Waage, S. 2000. Influence of new infection with bovine virus diarrhoea virus on udder health in Norwegian dairy cows. Prev. Vet. Med. 43:123-135.

Wilson, D. J., C. Rossiter, H. R. Han, and P. M. Sears. 1993. Association of Mycobacterium paratuberculosis infection with reduced mastitis, but with decreased milk production and increased cull rate in clinically normal dairy cows. Am. J. Vet. Res. 54:18511857.

WTO (World Trade Organization). 1994. Final Act of the 1986-1994 Uruguay Round of Trade Negotiations. http://www.wto.org/ english/docs_e/legal_e/ursum_e.htm Accessed Nov. 3, 2006.

Wu, J. T., S. Dreger, E. Y. Chow, and E. E. Bowlby. 2002. Validation of 2 commercial Neospora caninum antibody enzyme linked immunosorbent assays. Can. J. Vet. Res. 66:264-271. 